\title{
ATTEMPTS TO IMPROVE THE MATHEMATICAL COMMUNICATION SKILLS OF CLASS VB STUDENTS OF SDN 074 AYUDIA THROUGH THE TUTOR-ASSISTED SCIENTIFIC APPROACH
}

\author{
Ibnu Imam Al Ayyubi ${ }^{1}$, Nendi Rohaendi ${ }^{2}$ \\ ${ }^{1,2}$ Master of Mathematics Education, IKIP Siliwangi \\ 'hayugan 31@yahoo.com, ${ }^{2}$ nerorhoma@ rocketmail.com
}

Received: Jun 29 ${ }^{\text {th }}$, 2019; Accepted: Jul 29 $9^{\text {th }}, 2019$

\begin{abstract}
This research is motivated by the low mathematical communication skills of elementary schoolstudents who need a learning approach to overcome these problems. The alternative approach used is a scientific approach to peer tutoring. This study aims to examine whether the mathematical communication skills of students who use scientific learning are better than those who use ordinary learning to be reviewed from each stage of the cycle. The research method used is a qualitative method in the form of Classroom Action Research (CAR). In each cycle, learning is given first and then given a test. The population in this study were students of SDN 074 Ayudia Kota Bandung class V, while the sample was VB class. Data collection in this study is in the form of tests in each cycle, then the score data of mathematical communication skills are analyzed by descriptive statistics. Based on the results of the study, the authors concluded that students' mathematical communication skills increased from one cycle to the next.
\end{abstract}

Keywords: Mathematical Communication and Scientific Approach

\begin{abstract}
Abstrak
Penelitian ini dilatarbelakangi oleh rendahnya kemampuan komunikasi matematis siswa Sekolah Dasar yang diperlukan pendekatan pembelajaran untuk mengatasi masalah tersebut. Alternatif pendekatan yang digunakan adalah pendekatan saintifik berbatuan tutor sebaya. Penelitian ini bertujuan untuk menelaah apakah kemampuan komunikasi matematis siswa yang menggunakan pembelajaran saintifik lebih baik daripada yang menggunakan pembelajaran biasa untuk ditinjau dari setiap tahapan siklusnya. Metode penelitian yang digunakan adalah metode kualitatif dalam bentuk Penelitian Tindakan Kelas (PTK). Pada setiap siklus diberikan pembelajaran terlebih dahulu kemudian diberikan tes. Populasi dalam penelitian ini adalah siswa SDN 074Ayudia Kota Bandung kelas V, sedangkan sampelnya adalah kelas VB. Pengumpulan data dalam penelitian ini berupa tes pada setiap siklusnya, kemudian data skor kemampuan komunikasi matematis tersebut dianalisis dengan statistik deskriptif. Berdasarkan hasil penelitian, penulis menyimpulkan bahwa kemampuan komunikasi matematis siswa meningkat dari siklus satu ke siklus berikutnya.
\end{abstract}

Kata Kunci: Komunikasi Matematik dan Pendekatan Saintific

How to Cite: Al-Ayyubi, I. I., \& Rohaend, N. (2019). Upaya Meningkatkan Kemampuan Komunikasi Matematik Siswa Kelas VB SDN 074 Ayudia Kota Bandung pada Materi Pengolahan Data Melalui Pendekatan Saintific. JIML, 2 (3), 96-103.

\section{INTRODUCTION}

Mathematics learning is basic and compulsory learning at every level of education ranging from basic education to higher education. The importance of mastery of mathematics can be 
seen in the Law of Republic Indonesia No. 20 of 2003 concerning National Education System Article 37 affirmed that mathematics subjects are one of the compulsory subjects for students in primary and secondary education (Rahmawati, 2013). Mathematical communication is the ability / skill of students in expressing a vision or idea of mathematics and also completing written problems (Mardhiyanti, Putri, \& Kesumawati, 2011). In line with this, Ariani (2017)stated that mathematical communication ability is the ability to convey mathematical opinions / ideas, both oral and written writing and the ability to support and accept other people's mathematical motivations / ideas carefully, analytically, critically, and evaluatively to sharpen understanding. In another study that is more relevant to this research, Yuniarti (2014)stated that communication is the process of expressing ideas or understanding and understanding mathematically using numbers, images, and words, in various communities depending on teachers, peers, groups, or class. Mathematical communication skills (mathematical communication) is one of the basic and essential abilities of mathematics that must be possessed by students at elementary (elementary) or middle level. The implementation of the 2013 curriculum especially at the elementary school level with scientific learning in it, communication skills is one of the mandatory steps or stages in developing lesson plans (RPP), namely communicating. This shows that communication skills, especially mathematical communication is one of the important things for students in elementary school.

The importance of mathematical communication skills is also found in the curriculum and objectives of secondary school mathematics learning contained in Hard Skills and Soft Skill Mathematics Students (Herdiana, Rohaeti, \& Sumarmo, 2017). To support efforts to improve students' mathematical communication skills, there needs to be a way that is applied in learning. In this case, the attempt or method that will be applied is the application of a scientific approach assisted by peer tutors. Scientific approach is a learning process that is designed so students can actively construct concepts, principles through the stages of observing, formulating problems, submitting hypotheses, collecting data, drawing conclusions, and communicating (Machin, 2014), while peer tutoring approaches are approaches or ways of learning which involves classmates in the class so that learning doesn't feel awkward. Peer tutoring method is a method of learning that is done by empowering students who have high absorption from the group of students themselves (Arjanggi \& Suprihatin, 2010). The author's observations, in general, are still found tendency and student assessment of mathematics learning is difficult learning. This was also felt at SDN 074 Ayudia, Bandung, especially VB graders for the 2018/2019 school year. Mathematical learning involving counting operations in the story on data processing material content is still felt to be difficult by most students, it is illustrated by student learning outcomes in working on the story about data processing in the previous school year or in the 2017/2018 school year which is still widely available students get scores below the Minimum Criteria of Mastery Learning (KKM) which is 78. This shows that the communication skills of fifth-grade students of SDN 074 Ayudia are still low. An overview of grades V SDN 074 Ayudia 2017/2018 in the graph below. 
98 Al Ayyubi \& Rohaendi, Upaya Meningkatkan Kemampuan Komunikasi Matematik Siswa Kelas VB SDN 074 Ayudia Kota Bandung pada Materi Pengolahan Data Melalui Pendekatan SaintificBerbantuan Totur Sebaya

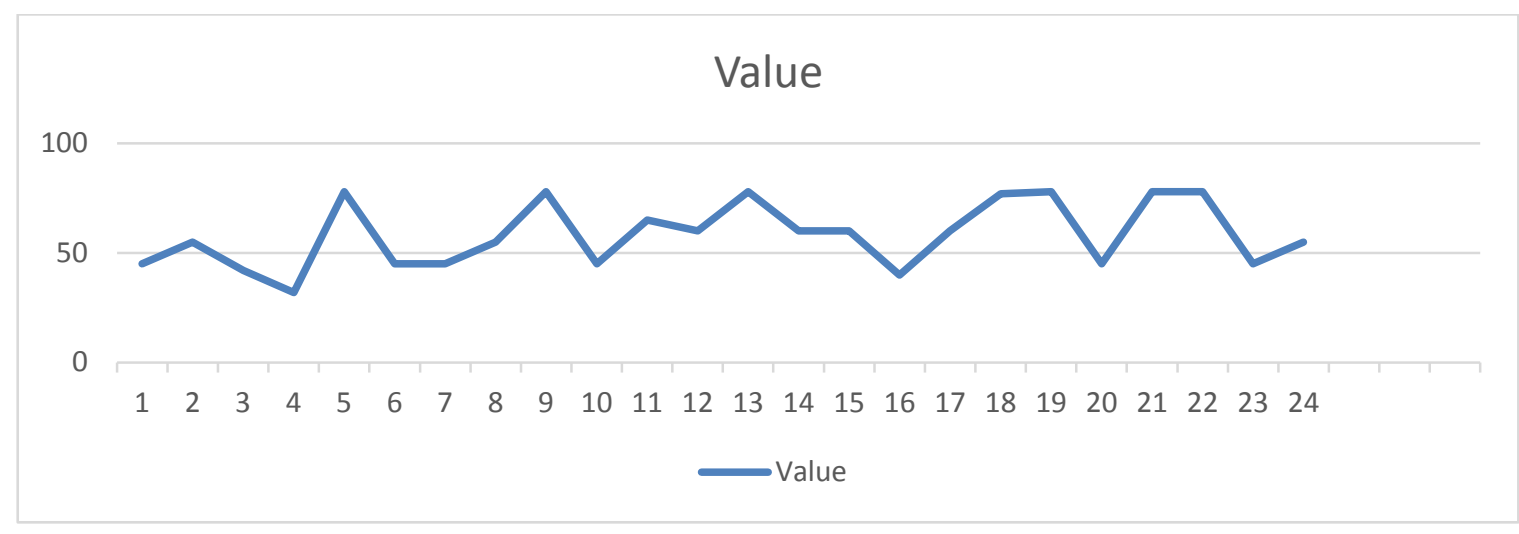

Figure 1. Marks of Class V Students in 2017/2018 School Year on Data Processing Materials

Based on the chart above, obtained data about the average mark of fifth-grade students of SDN 074 Ayudia in the school year 2017/2018 is 59.125. This needs attention and there must be improvements to enhance the students' communication skills especially to support peer tutors.

Basically, mathematical communication skills are essential components of mathematical hard skills that need to be owned and developed for students who study mathematics (Qodariyah \& Hendriana, 2015). In line with this,states that mathematical communication is an essential mathematical basic competence of mathematics and mathematics education.Without good communication, the development of mathematics will be hampered. Based on some of these references, mathematical communication skills can be defined as one essential component of mathematical hard skills in the form of student skills to express a situation into a mathematical model. Mathematical communication indicators according to (Sumarmo, 2010) include: a) Expressing real objects, situations, and everyday events into mathematical models (images, tables, diagrams, graphs, algebraic expressions); b) Explain ideas, and mathematical models (images, tables, diagrams, graphs, algebraic expressions) into ordinary languages; c) Explain and make mathematical questions learned; d) Listen, discuss and write about mathematics; e) Reading with an understanding of a written presentation; f) Creating conjectures, composing arguments, formulating definitions, and generalizing. Indicators of mathematical communication skills are felt to be relevant to mathematics learning in elementary schools because the content indicator is almost all of the content in mathematics learning is given in elementary schools, so this indicator will be used as a benchmark in making test instruments. While the scientific approach is an approach used in 2013 curriculum learning in elementary schools. The scientific approach in the 2013 curriculum can be combined with other approaches so that it is expected that student learning outcomes in particular in mathematical communication skills can increase. The companion of the scientific approach that is applied is the peer tutoring approach. To save time and streamline existing resources, students can also be learning resources or facilitators in good learning (Izzati, 2015).

The activities of students in learning that use a scientific approach assisted by peer tutoring approaches in elementary schools include: observing, asking, trying, reasoning and communicating combined with the presence of accompanying students of other students or tutors in each step of learning especially when working on mathematical questions.The material that becomes the focus of the research is the material for data processing in 
elementary school grade V is the mandate of Basic Competency (KD) of elementary school mathematics subjects, namely KD 3.8 which describes explaining the presentation of data addressing with participants and comparing data from the environment, tables, diagrams images (pictograms), bar charts, or line diagrams. Who revealed Learning to process data in grade $\mathrm{V}$ elementary school, discussed a number of issues that must be discussed, reviewed student difficulties that change available data in the form of tables, diagrams, determining mean, median and mode.

\section{METHOD}

The method of this research is qualitative research in the form of Classroom Action Research (CAR). The definition of CAR according to contained in the book Understanding Classroom Action Research: Theory and Application explains that:

"Action research is a form of self-reflective enquiry undertaken by participants in social (including education) situations in order to improve the rationality and juctice of (a) their own social or education practices, (b) their understanding of these practices, and (c) the situation in whice the practices are carried out. It is most rationally empowering when undertaken by participants collaboratively, thought it is often undertaken by individual, and sometimes in cooperation with outside."(Hanifah, 2014).Widayati (2008) Class Action Research (CAR) is a class contextual research activities carried out to solve the problems faced by the teacher in order to improve the quality and outcomes of learning and trying out new things to enhance the quality of education and learning outcomes. The research design used the CAR Kemmis and Mc Taggart designs. The design of the Kemmis \& McTaggart model consists of four components which are seen as a cycle, in this case, it is a cycle of activities consisting of planning, action, observation, and reflection. Based on reflection, then a plan designed (improvement), action and observation and reflection are arranged, and so on. The research procedure is in the form of a cycle consisting of three cycles. Data processing is achieved using qualitative data analysis. Data processing is obtained from the calculation of the average mark (mean) of students in communication skills mathematics using a scientific approach in one class in each cycle. The research subjects studied during this classroom action research activity were all VB graders at SDN 074 Ayudia in the academic year 2018 / 2019. The VB class students numbered 39 students, consisting of 18 male and 21 female students.

\section{RESULTS AND DISCUSSION}

\section{Results}

Students' mathematical communication skills using a scientific approach assisted by peer tutoring approaches in each cycle have increased. It is seen from the increase in student learning outcomes after working on the evaluation test of the story about data processing calculated by the class average score. 
100 Al Ayyubi \& Rohaendi, Upaya Meningkatkan Kemampuan Komunikasi Matematik Siswa Kelas VB SDN 074 Ayudia Kota Bandung pada Materi Pengolahan Data Melalui Pendekatan SaintificBerbantuan Totur Sebaya

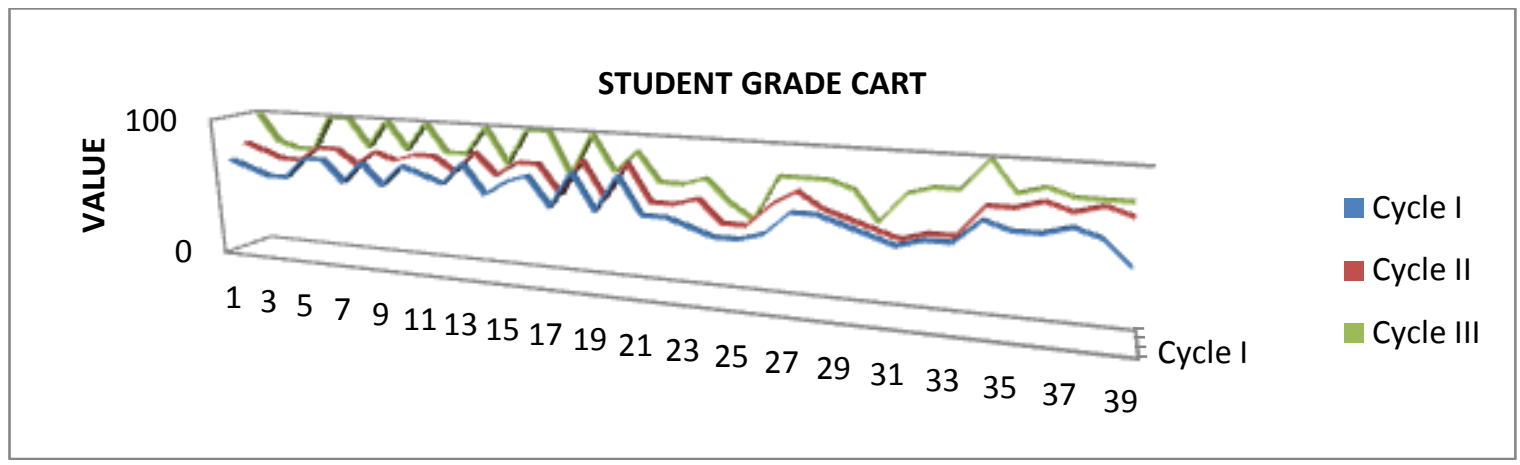

Figure2. The Improvement of Student Learning Outcomes for Each Cycle

\section{Discussion}

Based on data of graph 2, shows an increase in value, this reveals that students' communication skills have improved in each cycle. In cycle one, the average mark of students is 62.94 , in cycle two 70.25 and cycle three 81.92 . The same thing can be seen from the performance of students in each cycle that looks more enthusiastic, active and can take part in scientific learning assisted by peer tutors according to the stages given. Calculation of student performance based on scientific learning observation sheets assisted by peer tutors made and filled in by observers during the learning process shows an increase in each cycle. Enhancing student performance during learning can be seen in Figure 3 and the documentation.

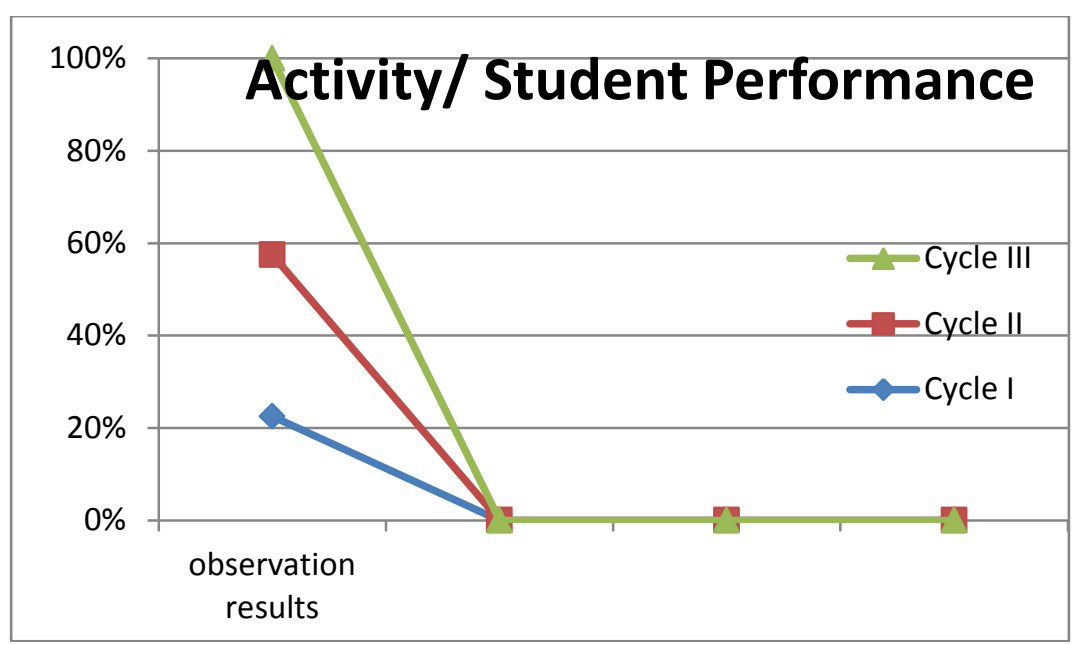

Figure 3.The Improvement Student Learning Outcomes for Each Cycle
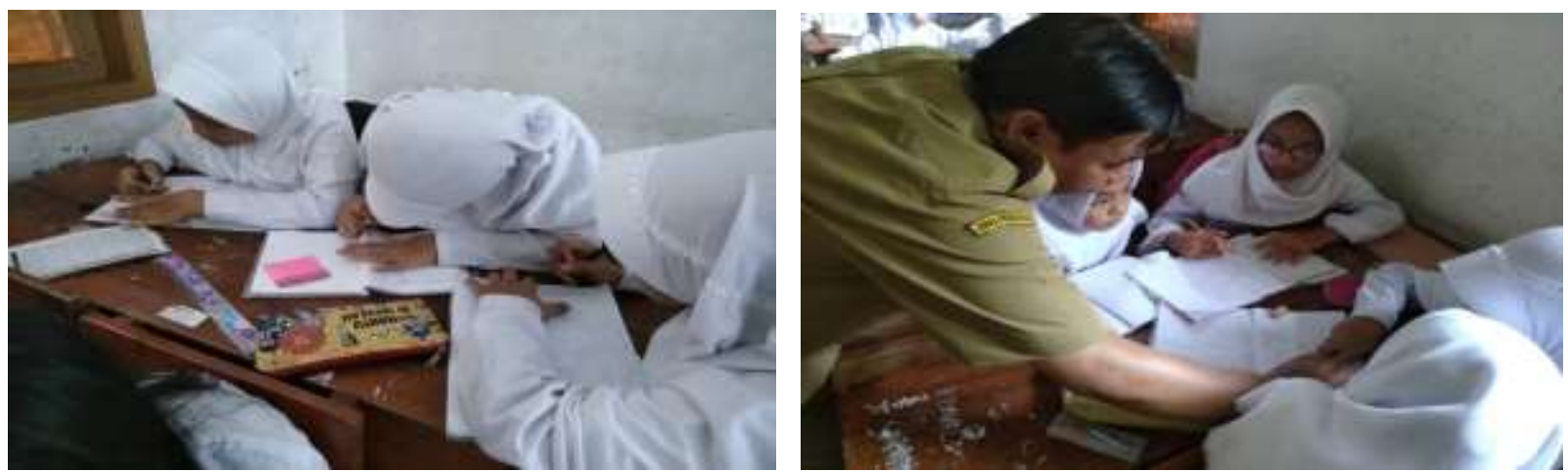

Figure4. Students Performances 
Based on Figure 3, there is an improvement in the percentage of students performance/activity using scientific learning assisted by peer tutors in each cycle. In cycle one, the percentage of student performance is $45 \%$, which means that student performance is still low. There is an elevation in the second cycle with a percentage of the performance of $70 \%$, which means that the performance of students is high. In the third round, the performance of students also reports a significant percentage which is $85 \%$. Students' problems in scientific learning assisted by peer tutors occur in the summarizing process, this is indicated by only a few students can conclude the learning material either orally or in writing. Students' difficulties in acquiring the material happen in the presentation of data in the form of diagrams. In accordance with the problems of the students in mastering the data presentation material in the form of charts, this is the same with the work on the presentation of data in the form of a graph and determining the median of some students still having difficulty in doing it.

In general, students' mathematical communication skills in each cycle increase, although it's gradual and not completed yet. To introduce and use mathematics as a communication language for students at school, it has to be done carefully and gradually (Umar, 2012).Interactions occur between students which are shown to be exchanging opinions and understanding when learning takes place. Through mathematical communication students exchange and explain their ideas or understanding to their friends(Hendriana, Sumarmo, \& Rohaeti, 2013). In addition to the mathematical communication skills that increase gradually, student cooperation in the learning process also increases, this is in line with the results of Apriyani dan Harta (2013) which states that the use of Peer Tutor models can improve student collaboration in mathematics learning Two-way interactions between teachers and students in groups during the learning process also often occur. peer tutoring learning models in small groups of students become skilled and dare to express their opinions in the learning process (Ribowo, 2006). Peer tutor learning emphasizes collaboration, discussion, active presentation so that it influences student learning outcomes (Sari, 2006). The scientific approach assisted by peer tutors given in learning is felt to be sufficient to support attempts to improve mathematical communication skills. Students, in general, can take part in learning and work on evaluation questions and master the material whose delivery is associated with something that is a students' daily basis experiences (contextual). The existence of contextual problems as the starting point of the learning process is able to make students more active in producing and constructing their knowledge by making mathematical models (Rahmawati, 2013).Contextual issues will make it easier for students to solve the problems given, this is also in accordance with the cognitive stages of elementary school students who, according to Piaget's theory, are still in concrete operations. In the concrete operational stage, children are mature enough to use logical or operating thinking, but only for physical objects that exist today (Ibda, 2015). In the concrete operational stage children can understand operations (logically) with the help of concrete objects (Alhaddad, 2012). The difficulties of students in completing questions about data processing occur at the stage of presenting data in the form of diagrams and determining the median, it has been stated in the research of Andrianti(2016) which reveals the learning of data processing in class V SD, there are several problems that must be considered, including difficulties of students in converting available data into tables, diagrams, determining mean, median and mode.

\section{CONCLUSION}

Mathematical communication skills of Grade VB Elementary School Students of SDN 074 Ayudia Bandung by utilizing a scientific approach assisted by peer tutors can increase 
102 Al Ayyubi \& Rohaendi, Upaya Meningkatkan Kemampuan Komunikasi Matematik Siswa Kelas VB SDN 074 Ayudia Kota Bandung pada Materi Pengolahan Data Melalui Pendekatan SaintificBerbantuan Totur Sebaya

mathematical communication skills from one cycle to the following ones. This can be perceived from the mark of student evaluations in the form of tests of mathematical communication skills about data processing which have increased in each cycle. The similar thing happened to the students' performance during the learning process by adopting a scientific approach assisted by peer tutors, in each cycle, there was an increase in the percentage of performance. This is indicated by an increase in the percentage of students performance based on calculations of assisted scientific learning observation sheets of peer tutors. Students' difficulties in mastering data processing materials occur in the presentation of data material in the form of diagrams and median material, in line with the difficulties of students in solving data processing questions in the form of presenting data in the form of diagrams and determining the median.

\section{ACKNOWLEDGMENTS}

Based on the research, some suggestions can be given are: 1) the provision of prerequisite material will be sufficient to assist in mastering various mathematical abilities of students; 2) giving rewards to children especially elementary students who can do something in learning will have a major impact on the application of any approach used during learning; 3) linking material and questions to something that is contextual or something that exists in the environment will help students master the material and solve the questions given.

\section{REFERENCES}

Alhaddad, I. (2012). Penerapan Teori Perkembangan Mental Piaget pada Konsep Kekekalan Panjang. Infinity, 1(1), 31-44.

Apriyani, D., \& Harta, I. (2013). Upaya Meningkatkan Kerjasama Siswa dalam Pembelajaran Matematika melalui Model Pembelajaran Tutor Sebaya. Surakarta: Universitas Muhammadiyah Surakarta.

Ariani, D. N. (2017). Strategi Peningkatan Kemampuan Komunikasi Matematis Siswa SD/MI. Jurnal Madrasah Ibtidaiyah, 3(1), 1-12.

Arjanggi, R., \& Suprihatin, T. (2010). Metode Pembelajaran Tutor Teman Sebaya Meningkatkan Hasil Belajar Berdasar Regulasi-Diri. Makara, Sosial Humaniora, 14(2), 91-97.

Hanifah, N. (2014). Memahami penelitian tindakan kelas: teori dan aplikasinya. (Julia, Ed.) (1st ed.). Sumedang: UPI Press.

Hendriana, H., Sumarmo, U., \& Rohaeti, E. E. (2013). Kemampuan Komunikasi Matematik serta Kemampuan dan Disposisi Berpikir Kritis Matematik. Jurnal Matematika Dan Pendidikan Matematika, 2(1), 35-45.

Herdiana, H., Rohaeti, E. E., \& Sumarmo, U. (2017). Hard Skills dan Soft Skill Matematik Siswa. (N. F. Atif, Ed.), Worksheets begin on page 325 (1st ed., Vol. 1). Bandung: PT Refika Aditama.

Ibda, F. (2015). Perkembangan Kognitif: Teori Jean Piaget. Jurnal Intelektualita, 3, 27-38.

Izzati, N. (2015). Pengaruh Penerapan Program Remedial dan Pengayaan melalui Pembelajaran Tutor Sebaya. EduMa, 4(1), 55-68.

Machin, A. (2014). Implementasi Pendekatan Saintifik, Penanaman Karakter dan Konservasi pada Pembelajaran Materi Pertumbuhan. Jurnal Pendidikan IPA Indonesia, 3(1), 28-35.

Mardhiyanti, D., Putri, R. I. I., \& Kesumawati, N. (2011). Pengembangan Soal Matematika Model Pisa untuk Mengukur Kemampuan Komunikasi Matematis Siswa Sekolah Dasar. Jurnal Pendidikan Matematika, 5(1), 1-14. 
Qodariyah, L., \& Hendriana, H. (2015). Mengembangkan Kemampuan Komunikasi dan Disposisi Matematik Siswa SMP Melalui Discovery Learning. Edusentris, Jurnal Ilmu Pendidikan Dan Pengajaran, (D1), 241-252.

Rahmawati, F. (2013). Pengaruh Pendekatan Pendidikan Realistik Matematika dalamMeningkatkan Kemampuan Komunikasi MatematisSiswa Sekolah Dasar. Kumpulan Makalah Seminar Semirata, 225-238.

Ribowo, B. (2006). Upaya Meningkatkan Hasil Belajar Siswa Kelas IIA SMP Negeri 2 Banjarharjo Brebes dalam Pokok Bahasan Segiempat Melalui Model Pembelajaran Tutor Sebaya dalam Kelompok Kecil Tahun Pelajaran 2005/2006. Brebes: Universitas Negeri Semarang.

Sari, I. M. (2006). Keefektifan Model Pembelajaran Tutor Sebaya Terhadap Hasil Belajar Matematika Pokok Bahasan Persmaan Garis Lurus Siswa Kelas VIII. Semarang: Universitas Negeri Semarang.

Sumarmo, U. (2010). Berpikir Dan Disposisi Matematik: Apa, Mengapa, dan bagaimana dikembangkan pada peserta didik. Bandung: FPMIPA UPI.

Umar, W. (2012). Membangun kemampuan komunikasi matematis dalam pembelajaran matematika, $1(1)$.

Widayati, A. (2008). Penelitian Tindakan Kelas. Jurnal Pendidikan Akuntasi Indonesia, VI(1), 87-93.

Yuniarti, Y. (2014). Pengembangan kemampuan komunikasi matematis dalam pembelajaran matematika di sekolah dasar. EduHumaniora, 6(c), 109-114. 